Ann. Génét. Sél. anim., I977, 9 (2), I63-180.

\title{
Gharacteristics of some less-common breeds of sheep in Southern Europe : a preliminary survey
}

\author{
C. H. BROOKE and M. L. RYDER (*)
}

Department of Geography, Portland State University, Portland, Oregon 97207 (USA)

$\left(^{*}\right)$ A.R.C. Animal Breeding Research Organisation, Edinburgh EH93 JQ (UK).

\section{Summary}

Preliminary findings of a field study of Mediterranean sheep are presented for twelve of the fifty-three breeds surveyed during the period September 1974-August 1975: Spanish Merino, Levant Red (Spain); Peone (France); Carapelle (Italy); Dubrovnik (Yugoslavia); Katafigion, Skopelos, Chalkidiki, Drama native, (Greece); Sakiz, Imroz, Ödemis (Turkey). For disappearing breeds, factors which account for decline are identified. Each breed is briefly discussed as to its location, present population and trend, significant morpholegical and performance characteristics, management, and adaptive conditions. Breeds are identified whose fleece and skin samples showed affinity to fine-wooled types.

\section{Introduction}

This paper is a preliminary and partial report of a survey to seek out and identify the less-common breeds of sheep in Mediterranean Europe and western Anatolia, to map their distribution, and to ascertain their populations and rates of change. The object was also to identify breeds in danger of extinction, and to determine the factors contributing to their decline.

Where published details were lacking or inadequate, it was proposed to record breed characteristics, performance data, and adaptive qualities. Unimproved sheep likely to throw light on the affinities and evolution of modern breeds were also sought, with particular reference to the spread of the fine-wooled type around the Mediterranean, and its emergence in Spain as the Merino breed.

The field investigation for the study, supported by a grant from the National Science Foundation (U.S.A.), was carried out from September 1974 to mid-August 
I975. The work was done in cooperation with the Animal Production and Health Division, FAO, Rome. The FAO has a long-standing interest in animal genetic resources, and, in this regard, our study provides continuity to J.-J. LAUVERNE's survey of disappearing breeds of cattle in Europe and the Mediterranean basin (LAUVergne, I975; Collins, I975)

\section{Methods}

The scope of the survey was similar to that of MAson (I967), except that it was limited to countries north of the Mediterranean: Portugal, Spain, France, Italy, Yugoslavia, Greece, and Turkey. Fifty breeds were investigated, and these are listed Table $\mathrm{I}$.

TABLE I

List of all breeds surveyed (by country)

Liste de toutes les races passées en revue (pays par pays)

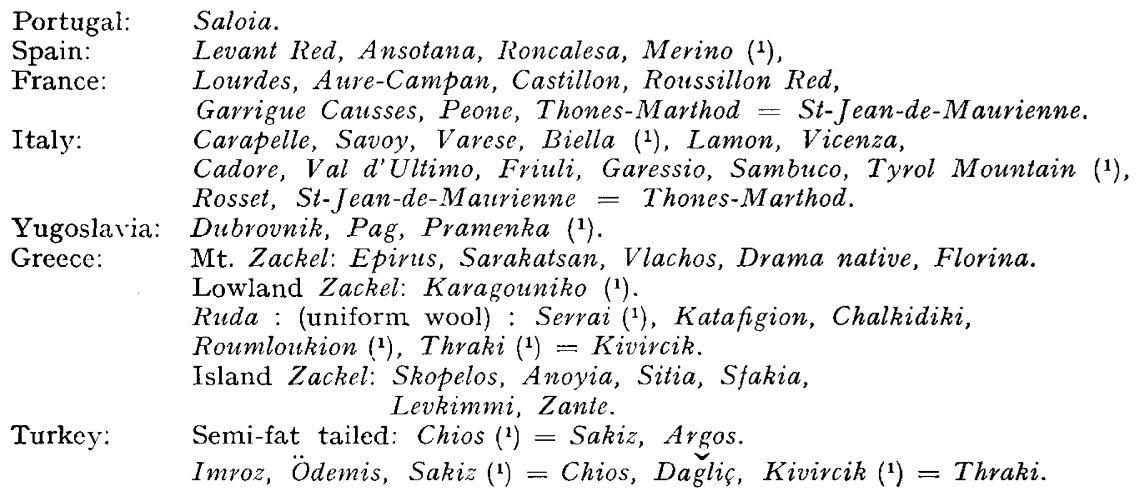

(r) Common breed surveyed for comparison.

Flocks visited were either the only ones available, or the only ones accessible. Animals chosen for measurement, photography, or fleece sampling were selected at random among sheep judged by the owner to be the most primitive or the most typical. The source of such data as body weight or lambing percentage is indicated with the breed descriptions in order to distinguish between records and opinions.

The details recorded included height at withers, body weight, lambing percentage, milk production, methods of husbandry, and fleece type, for which wool and skin samples were taken from most of the breeds. These were removed from the standard mid-side position, diameter measurements were made using the standard LWTO projection microscope method, and the skin was sectioned and 


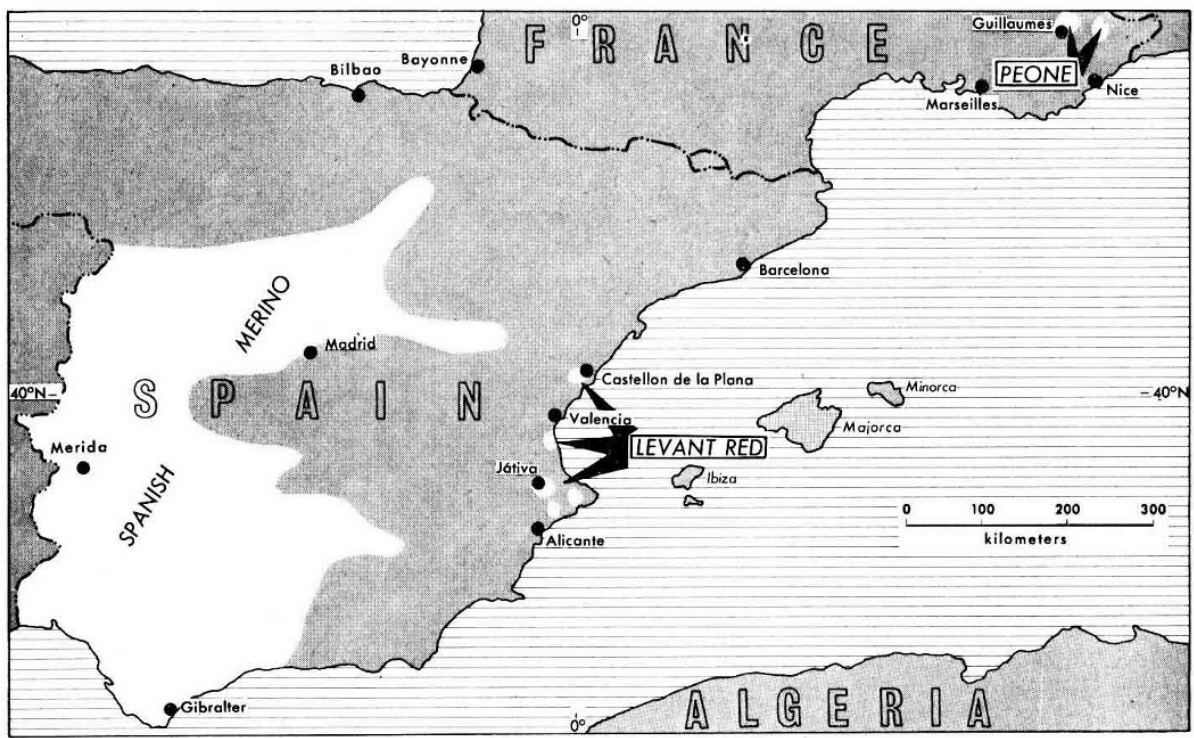

FIG. I. - Western Mediterranean: location of Spanish and French sheep breeds discussed in this paper. Localisation des races étudiées dans l'article dans la zone méditerranéenne occidentale.

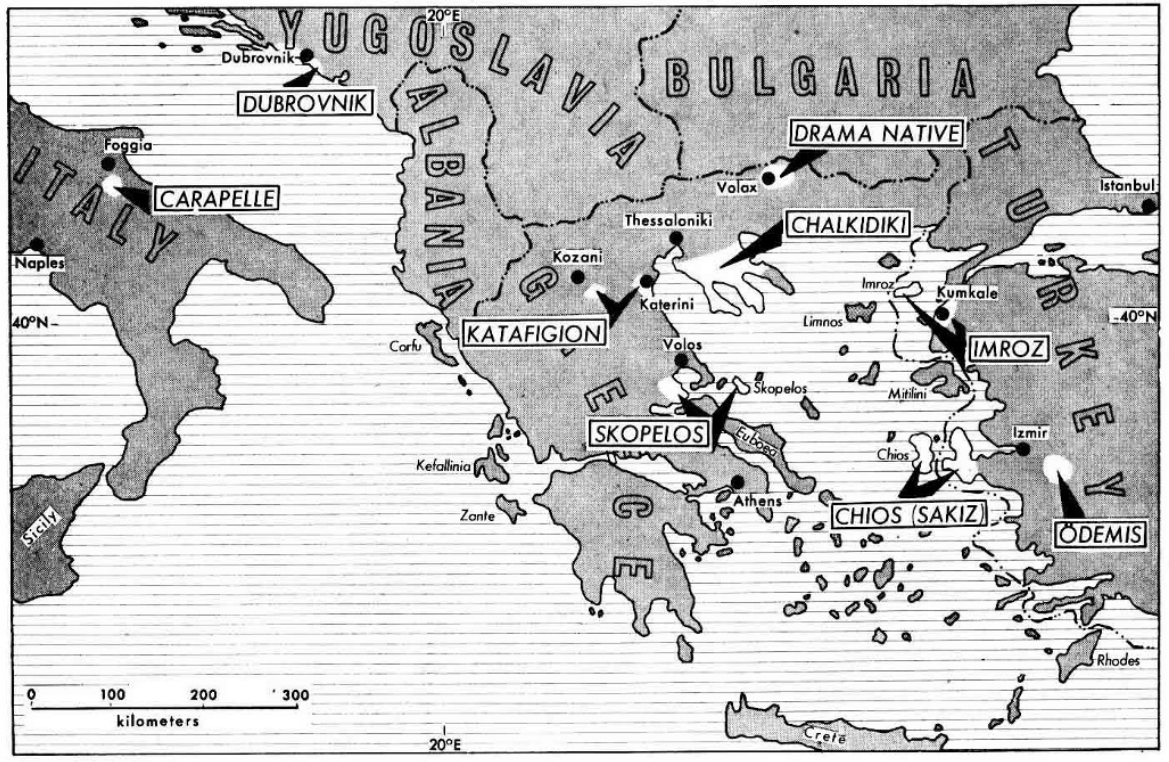

FIG. 2. - Eastern Mediterranean: location of Italian, Yugoslavian, Greek and Turkish sheep breeds discussed in this paper.

Localisation des races étudiées dans l'article dans la zone méditerranéenne orientale. 
follicle counts made by the methods in Appendix I of RYDER and STEPHENSON (I968).

The twelve breeds discussed in this paper do not constitute all of the breeds surveyed whose survival is threatened, but they do meet one or more of the following criteria: (I) the breed is close to extinction, with the resultant loss of genetic variation; (2) the breed has not previously been described in the literature, or, present knowledge of it is incomplete or obsolete; (3) examination of wool and skin samples from the breed provides new evidence for affinity to other breeds. Their locations are given on the maps of figures $x$ and 2 respectively for the western and the eastern part of the Mediterranean basin.

\section{Breed descriptions}

$$
\text { A. - Spain }
$$

Spanish sheep can be classified into three types (a) Merino, (b) coarse-fleeced, and $(c)$ crosses between these two (entrefino).

I. The Merino was originally divided into stationary flocks, and more slender and longer-legged, migratory sheep. As transhumance declines, originally migratory flocks are now becoming stationary, and at least one of the three flocks seen near Merida in Extremadura has originally been migratory (fig. $3 a$ ).

Although variable, the wool in the ten samples taken was at least 70 os quality. (Commercial wool quality is measured on a numerical scale, the definition of which is given by RYDER and STEPHENSON, I968). The mean fibre diameters ranged from I8. I to $24.4 \mu$ with a mean of 2 I.3. The modes (most frequent values) ranged from 18 to $24 \mu$ in diameter with a mean of 20.8 , indicating slightly skewed distributions. The mean staple length was $44 \mathrm{~mm}$.

Four of the animals were also skin sampled, and the $\mathrm{S} / \mathrm{P}$ follicle ratio ranged from 9.0 to $\mathrm{I} 2.8$ with a mean of I0.5/I. This compares with a figure of $\mathrm{I}_{4}$ for the "original " Camden Park Merinos, and the average figure of 20 for modern Merinos in Australia (Ryder and STEPHEnSON, I968).

These findings accord with previous suggestions (e.g. RYDER, I963) that the increase in fleece weight (from about $3 \mathrm{~kg}$ to $4.5 \mathrm{~kg}$ ) obtained in the Australian Merino has been due to increased fibre length and increased density of wool follicles in the skin, with little, if any, change in fibre diameter.

The Spanish Merino, although bred in the past for wool, has in more recent times been a triple-purpose sheep, and it is of immense historical interest as being the ancestor of all other Merinos throughout the world. It should therefore not

FIG. 3. - Sheep breeds surveyed in Spain, France, Italy, Yugoslavia and Greece.
a) Spanish Merino ewe
d) Carapelle ewe (Italy)
b) Levant Red ram
e) Dubrovnik ewe (Yugoslavia)
c) Peone (Maurerousse) ram (France)
f) Drama native ewe (Greece).
Races ovines observées en Espagne, France, Italie et Grèce.
a) brebis Merinos espagnol
d) brebis Carapelle (Italie)
b) bélier Rouge du Levant
e) brebis Doubrovnik (Yougoslavie)
c) bélier Peone (Maurerousse) (France)
f) brebis Drama indigène. 
be allowed to die out as a result of the crossing that is now taking place with improved Merino.

2. Levant Red (also, Guirra, or Sudat) is a breed found near the coast in the Spanish provinces of Alicante, Valencia, and Castellón de la Plana. During the past decade the breed has steadily declined to the extent that its survival is uncertain. In 1974, the total number of pure-bred Levant Red was reported to be I.336 (SANCHEZ BELDA, I974). Of these 397 were in the province of Alicante, all in six localities within a few kilometers of the shore (from Villajoyosa to Jávea). This northern section of the Costa Blanca is rapidly being transformed into a multistoried resort area. The open, uncultivated coastal areas, in which the sheep have traditionally grazed, are disappearing as more land is developed to accommodate the hundreds of thousands of tourists that come to this part of Spain each year. Almost all of the 844 Levant Red in the province of Valencia were in six places near the town of Játiva, about $25 \mathrm{~km}$ inland from the Costa del Azahar. In this area, sheep raising has declined as production and profits from horticulture (vine, citrus, fresh vegetables) have substantially increased. All of the 95 Levant Red sheep in Castellón de la Plana are kept by one owner near the outskirts of the provincial capital. In the course of our survey, Levant Red flocks were seen in all three of the provinces.

The early history of the breed is not known, but according to SANCHEZ BELDA (I976), the Levant Red developed from crossings of the Manchega with thin-tailed North African breeds. Except for about 5 per cent which were black, the color of the fleece of the animals seen during the survey varied from reddish-brown to yellow-white. The color of new-born lambs is dark reddish-brown. With age the coat lightens, becoming at full maturity a dirty cream color. Sheep with white coats are not considered to be pure Levant Red, nor are those that do not have reddish-brown legs. ("Guirra " is the word for "reddish " in the Valencian dialect; "sudat " means "greasy ", in reference to the oily condition of the uncleaned wool.) Both sexes lack horns. The tail is thin and of medium length.

The breed is notably frugal in its feeding requirements and appears to thrive on the poor, rough grazing of the region. Veterinarians reported that the breed is remarkably healthy. The Levant Red is considered to be a good milking breed, but today production is almost entirely for lambs (slaughtered three to four months after birth). In the recent past, milk was of primary value. Ewes have two ostrous periods annually, but usually lamb once a year with a twinning rate reported to range from 50 per cent to 80 per cent.

Of the five fleece samples taken, one animal had wool of almost Merino fineness, ranging is diameter from 16 to $36 \mu \mathrm{m}$ with a mean of 24.6 and a mode $27 \mu \mathrm{m}$, but its $\mathrm{S} / \mathrm{P}$ ratio was only 5.7 , lower than expected even for a Merino cross. The remaining four fleece samples had hairy fibres (mean percentage of medullated fibre I4.25 per cent) in addition to the bulk of the coat which ranged up to about $50 \mu \mathrm{m}$ in diameter. The mode or each was $24 \mu \mathrm{m}$, but the means ranged from 27.3 to 34.8 , with an overall mean of $3 \mathrm{I} \mu \mathrm{m}$. The mean $\mathrm{S} / \mathrm{P}$ ratio in the skin was $5.4 / \mathrm{I}$. By the the classification of RYDER (I969) these are hairy medium wools. The color and the suggestion of a tendency to moult indicate a primitive type akin to that of the Shetland in northern Europe, which also has fine as well as hairy fleeces, and a similar S/P ratio (RYDER, I968).

LYDEKKER (I9I2), p. 76, referred to a primitive colored breed of sheep in Spain called Ovejas marinas, and it is of interest that PLINY (Natural History VIII, I9I) stated that Spain was famous for black and brown sheep in Roman times. 


\section{B. - France}

The Peone (also, Maurerousse) is an old migrant breed of sheep found in the southeastern corner of France. The breed has been decreasing during the past twenty years as a result of crossings with Alpine, Arles Merino, and Préalpes $d u$ Sud. In Alpes-Maritime Department Peone are kept in the upper valleys of the rivers Vésubie and Var, with most of them in scattered holdings in the area of Guillaumes. The population of pure-bred Peone was reported to be approximately I.250, with about an equal number cross-bred. This is half the number reported in an earlier survey (GILBERT, I975a). Production is for meat (lamb), with wool accounting for only three per cent of the total value. The breed is not milked.

In general appearance, the Peone resembles the Rouge du Roussillon (fig. 3, c). In both breeds the head and legs are brown or reddish-brown, the fleece white, and the ears are medium long, nearly horizontal or drooping forward slight In this survey, significant differences were noted between the two breeds. Peone ewes are smaller animals: for mature ewes the mean wither height is $6 \mathrm{I} \mathrm{cm}$., compared to $73 \mathrm{~cm}$. for the Rouge du Roussillon; for mature rams: Peone $75 \mathrm{~cm}$., and Rouge $d u$ Roussillon 80-90 cm (GILBERT, I975b). In proportion to the trunk, the legs of the Peone are shorter. Unlike the Rouge du Roussillon, which has bare head and belly, the Peone has a top knot, and its fleece extends below the sides to cover the belly. The bridge of the nose is commonly white in both breeds, but the muzzle of the Peone is broader than that of the Rouge du Roussillon. Both sexes of the Rouge du Roussillon are polled; in the Peone, ewes are polled, and about half of the rams are horned.

From October to June flocks of Peone are kept in open pastures on the lower valleys where they are exposed to the cold and violence of the mistral. It was to produce cross-breeds immune to the effects of these bitterly cold winds that the Alpine (Commune des Alpes) and the Arles Merino were brought to the region. During the winter only ewes with lamb (and the few flocks that are in the high valleys) are stall fed. Individual holdings range from 200 to 300 head of pure and cross-bred sheep. In late June several holdings are combined into flocks of 800 to $\mathrm{I} 200$ sheep and walked from the valleys to the high grazing places in the moutains where they remain until October.

Ewes are in œstrous twice a year but usually lamb once per year, either during October-November or February-March. The lambing rate was reported to be between I 30 and I5O with about ten per cent mortality before market age (four to six months). Local breeders reported that although the Peone is less hardy and somewbat less frugal than the Alpine and Arles Merino, it is superior in these characteristics to the Préalpes $d u$ Sud.

The four fleece samples ranged from 20 to $40 \mathrm{~mm}$ in length, with a mean of $30 \mathrm{~mm}$. They were all clearly fine, with a quality of $58 \mathrm{~s}$, but lacked crimp. The wool therefore resembled that of a British Down type rather than Merino. The overall fibre diameter range was from I4 to $62 \mu \mathrm{m}$ the modes ranged from 26 to $40 \mu \mathrm{m}$ with a mean of $32.5 \mu \mathrm{m}$ and the mean diameters ranged from 27.9 to 35.3 to give an overall mean diameter of $32.7 \mu \mathrm{m}$. The similarity of the modes and means reflects the symmetrical diameter distribution, all being true medium fleece types, with one tending towards the fine type.

The three skin samples had the relatively high mean $S / P$ follicle ratio of $6.2 / \mathrm{I}$, which is, however, in keeping with the relatively fine mean fibre diameter (above). One animal had a small amount of non-latticed medullation in the pri- 
mary fibres making the overall mean 2 per cent; 13 per cent of the primary follicles, and 5 per cent of the secondaries showed evidence of regrowth after shedding (at the beginning of Juiy).

$$
\text { C. - Italy }
$$

The Carapelle is a triple-purpose sheep formerly kept in flocks of mixed breeds in the Carapelle valley southwest of Foggia, Italy. A local name is "Black Merino", although FEderconsorzi (I96I) identifies Carapelle as a variety of Moscia Leccese, a carpet-wool breed popular in Apulia. During the past twenty years the large agricultural estates in the area have been broken up into small holdings for irrigated farming, and the changes in the land-use and tenure system have brought about a precipitous decline in numbers of sheep there. The spread of hypericum $s p p$. concurrent with the introduction and extension of irrigation, also is a factor in the decline of sheep.

FEDERCONSORzI in I96I recorded only 300 Carapelle. Today the breed appears to be very near extinction. In our survey, only one Carapelle was found, a two-year old ewe, $6 \mathrm{I} \mathrm{cm}$. high at the withers. The coat was a very dark brown, and the face and legs were black and bare of wool (fig. 3,d). This sheep was horned according to FEDERCONSORZI (I96I) and MASON (I967) both sexes are polled.

The mean wool fibre diameter of $3 \mathrm{I} .2 \mu \mathrm{m}$ was higher than that of the local Merino, and S/P follicle ratio of 5.3 lower. Three samples taken from Gentile di Puglia sheep for comparison had a mean fibre diameter of $24.8 \mu \mathrm{m}$ and an $\mathrm{S} / \mathrm{P}$ follicle ratio of $8.9 / \mathrm{r}$. The Carapelle therefore appears to be of primitive, rather than Merino type.

\section{D. - Yugoslavia}

Dubrovnik. To the description of this white-faced, polled breed given by MAson, can be added the following points: the rams are sometimes horned, the nose is bare and slightly convex, but there is a wooly top knot (fig. 3e). The wool from the Io per cent of sheep with colored fleeces was desired in the past to make naturally-colored garments. The fleece weight is from one to two kg., and the tail is long.

In the recent past each peasant family had from fifteen to twenty sheep, but now only about one to six are held. The five flocks we saw numbered three to five ewes. The breeds is declining rapidly. Locally, tourism offers greater income than sheep husbandry and many young people today leave home to work in this and other industries. Barrenness is common because there is only one ram in each district, and no attempt is made to detect heat. But among ewes lambing there is $\mathbf{1} 45$ per cent lambing, and there is a long breeding season; ewes often lamb thrice in two years. Both sexes will mate in their first year.

The sheep are grazed in olive groves in the summer, and kept indoors during the winter, despite the mild climate. A common lambing time is late autumn, and lambs are killed at 35-40 days, crossbreds dressing out at about II kg. The ewe is then milked for cheese from February until July, the yield declining from a maximum of two litres at the beginning of lactation, to about one-half litre at the end.

As to the fleece, most fibres had a diameter within the range I5 to $55 \mu \mathrm{m}$, 
but of the nine samples taken, six had a few hairs ranging up to $88 \mu \mathrm{m}$ in diameter, and thus were hairy medium wools on the classification of RyDER (I969). These had a skewed diameter distribution, with the bulk of the fibres being fine, while the remaining three samples had a symmetrical distribution, being fine medium wools.

The overall mean diameter was $34 \mu \mathrm{m}$, and the average of the most frequent diameters was $3 \mathbf{I} \mu \mathrm{m}$. This is somewhat coarser than the figure of $28-30 \mu \mathrm{m}$ given by MAson. But even this is coarser than the quality of $58 \mathrm{~s}-6$ os he quotes. The wool lacks crimp and is no more than about 5 os quality. The mean percentage of medullated fibres was six per cent.

There was virtually no medullation in the skin, which is in keeping with the time of sampling in winter when medullation is lost. There was evidence of inactivity in 2-3 per cent of the follicles. The secondary/primary follicle ratio ranged from 3.5 to 6.0 with a mean of $4.7 / \mathrm{I}$.

The accepted view quoted by MAson is that the Dubrovnik breed derives from a recent cross between the Merino and the Pramenka, and introductions of the Merino into the area are well documented. But there are various features such as the lack of crimp, and the high lambing percentage, which suggest that this breed cannot derive solely from this cross. The $\mathrm{S} / \mathrm{P}$ ratio values obtained in the present study also oppose this origin. Assuming that the Merinos introduced would have had an S/P ratio as least as high as the Spanish Merino (Io/I, see above), the Dubrovnik would be expected to have a value intermediate (6.6) between this and that of the Pramenka (3.3); yet, the figure was only 4.7.

It therefore seems likely that the Dubrovnik is a relic of an ancient fine wool. This accords with historical evidence that this area had contacts with peoples who could have introduced such a sheep, and in the Middle Ages the city of Dubrovnik had a well-developed wool-textile industry.

\section{E. - Greece}

I. The Drama native breed, discovered in the village of Volax north of Drama, is not listed by MASON, but is probably a variety of the Vlachos (Mountain Zackel). Some animals were closely similar to the colored Vlachos sheep illustrated in his Plate I Io. The black sheep we saw (fig. I, f) had a relatively finer fleece than the remainder, and were also similar to the Chalkidiki sheep, (see below).

On the whole, however, as with other Greek breeds, the appearance was very variable: horned and polled animals, black, white and grey fleeces, speckled faces and legs, and a moderately long tail. Black around the eyes, and a woolly "top knot ", were common, as in other Greek breeds.

The sheep mate first at 20 months, and lamb only once a year, but the ewes are kept for eight years. Owing to barrenness and a Io per cent lamb mortality, the weaning percentage was only 80 per cent. Lamb provides 64 per cent of the income, milk 32 per cent and wool 4 per cent (fleece weight one $\mathrm{kg}$ ). In contrast, in the Serrai breed of the plain, 60 per cent of the income comes from milk, 35 per cent from meat and 5 per cent from wool.

In three of the five fleece samples taken the bulk of the wool was between I6 and $60 \mu \mathrm{m}$ in diameter, with a few hairs up to $70 \mu \mathrm{m}$ in diameter, making them hairy medium wools. Two of the sheep had a more continuous distribution with hairs up to II $2 \mu \mathrm{m}$ in diameter, being therefore true hairy types, although they had no more than Io per cent medullated fibres. The overall mean percentage of 
medullated fibres was 5 per cent. The mean diameter was 39.I $\mu \mathrm{m}$ (range 33.3 to $47.5 \mu \mathrm{m}$ ) and the average of the modes 3 I.6 $\mu \mathrm{m}$ (range 22 to $3^{8} \mu \mathrm{m}$ ).

There was no medullation at all in the skin, and I3 per cent of the primary, and 4 per cent of the secondary follicles were inactive. The S/P ratio of 3.2 was low (cf. Chalkidiki breed below).

2. The Katafigion is a migratory breed of the Pieria Mountains in southeastern Macedonia. It has almost disappeared as a result of cross-breeding and socioeconomic changes in the hearth of the breed. From a population of several thousand in I960 (GEORGIOU, I960), the number of pure-bred animals has declined to less than Ioo today. Very few pure Katafigion sheep remain, as they did formerly, on the western slopes of the Pieria. That area was toured extensively in the course of the survey but no sheep were found that could with certainty be identified as pure Katafigion. However, some pure-bred Katafigion were found at the town of Katerini among small flocks owned by former residents of Katafigion village. The village, set high in Pieria Mountains, had a population of several hundred families in the mid-I950's. At that time, each family maintained a flock of IOO-I 50 sheep. Today only a few elderly persons remain there. During the past twenty years the others left the village to establish new homes in Velvendos, in Katerini, and in other towns, where most of them have adopted an urban way of life. However, each year about thirty families from Katerini return to Katafigion village and remain there from May to October. Some families bring their sheep, transporting them by motor trucks.

Owners reported that the breed is unusually hardy and is eminently able to thrive on graze of poor quality. Production is for milk and lambs. For many years breeders have crossed the Katafigion with Greek Zackel (especially Karaganiko). In the course of our survey, it was reported that in I964 an artificial insemination programme was introduced in the Velvendos area to cross the Katafigion with the Chios and East Friesian breeds. The informant stated that the program was dropped after several years because the cross-bred sheep, unlike the pure-bred Katafigion, did not thrive unless given supplemental feed.

White is the prevailing color of the Katafigion breed (fig. 4 a). Speckled or brown sheep are not regarded as pure-bred. The face, legs, and (commonly) the belly are bare of wool. Most have a top-knot. The tail is thin and of medium length. Rams are horned; ewes polled. The nose is slightly convex, and the ears horizontal and of medium length. The wither heights of eight mature ewes ranged from $58 \mathrm{~cm}$ to $65 \mathrm{~cm}$, with a mean of $62 \mathrm{~cm}$. For the one ram that could be accepted as "probably pure-bred" the wither height was $70 \mathrm{~cm}$. Ewes are first mated at two-years of age, and it is common practice to breed for two lambings annually, in August and in February. The twinning rate is reported to be 50 per cent.

Frg. 4. - Sheep breeds surveyed in Greece and Turkey.
a) Katafigion ewe (Greece)
b) Chalkidiki ewe (Greece)
d) Chios (Sakiz) ewe (Greece)
c) Skopelos ram (Greece)
e) Odemis ewe (Turkey)
f) Imroz ewe (Turkey)
Races ovines observées en Grèce et en Turquie
a) brebis Katafigion (Grèce)
b) brebis Chalcidique (Grèce)
d) brebis Chios (ou Sakiz) (Grèce, Turquie)
c) bélier Skopelos (Grèce)
e) brebis Ödemis (Turquie)
f) brebis Imroz (Turquie) 

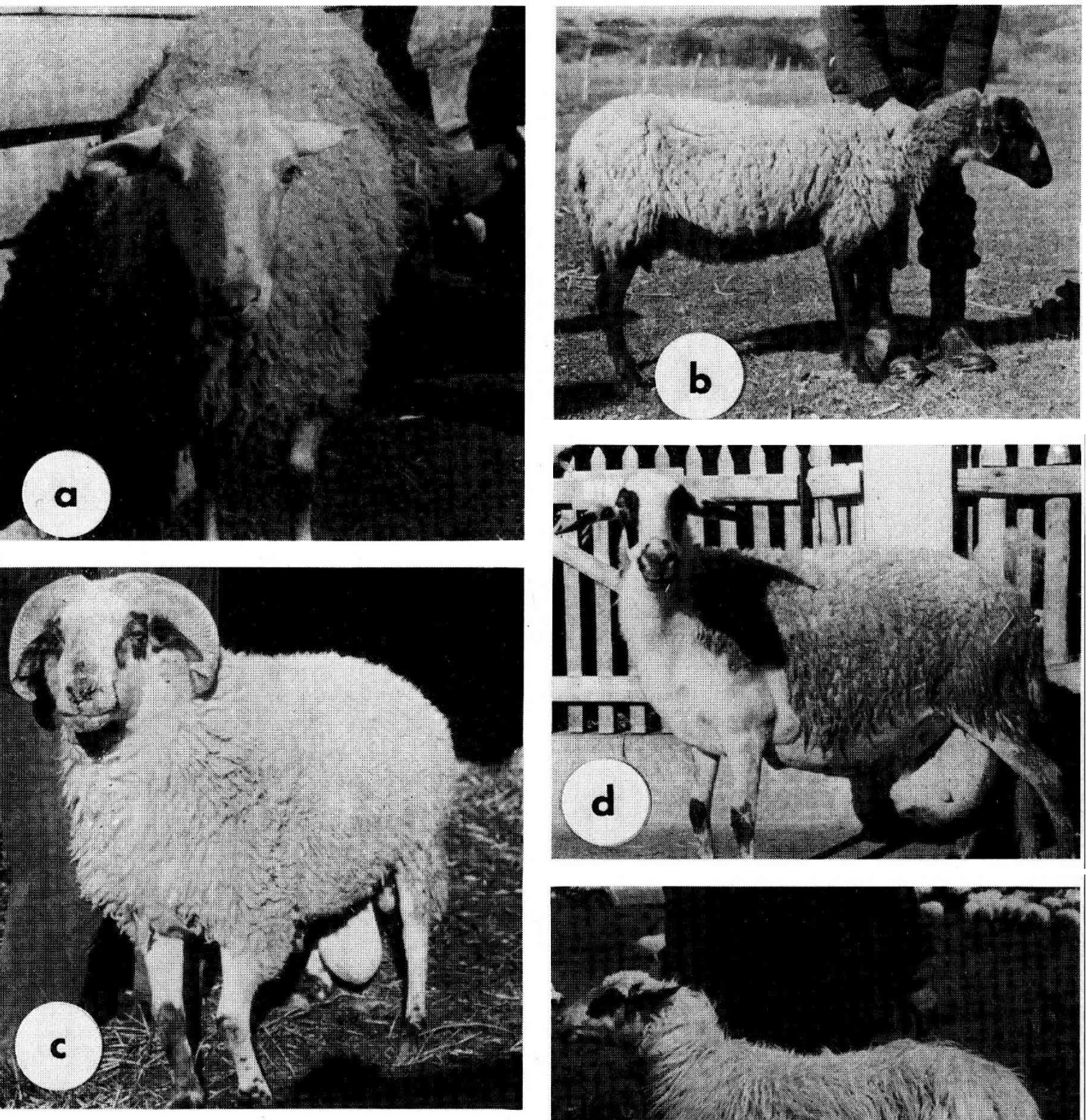

\section{minfulit}
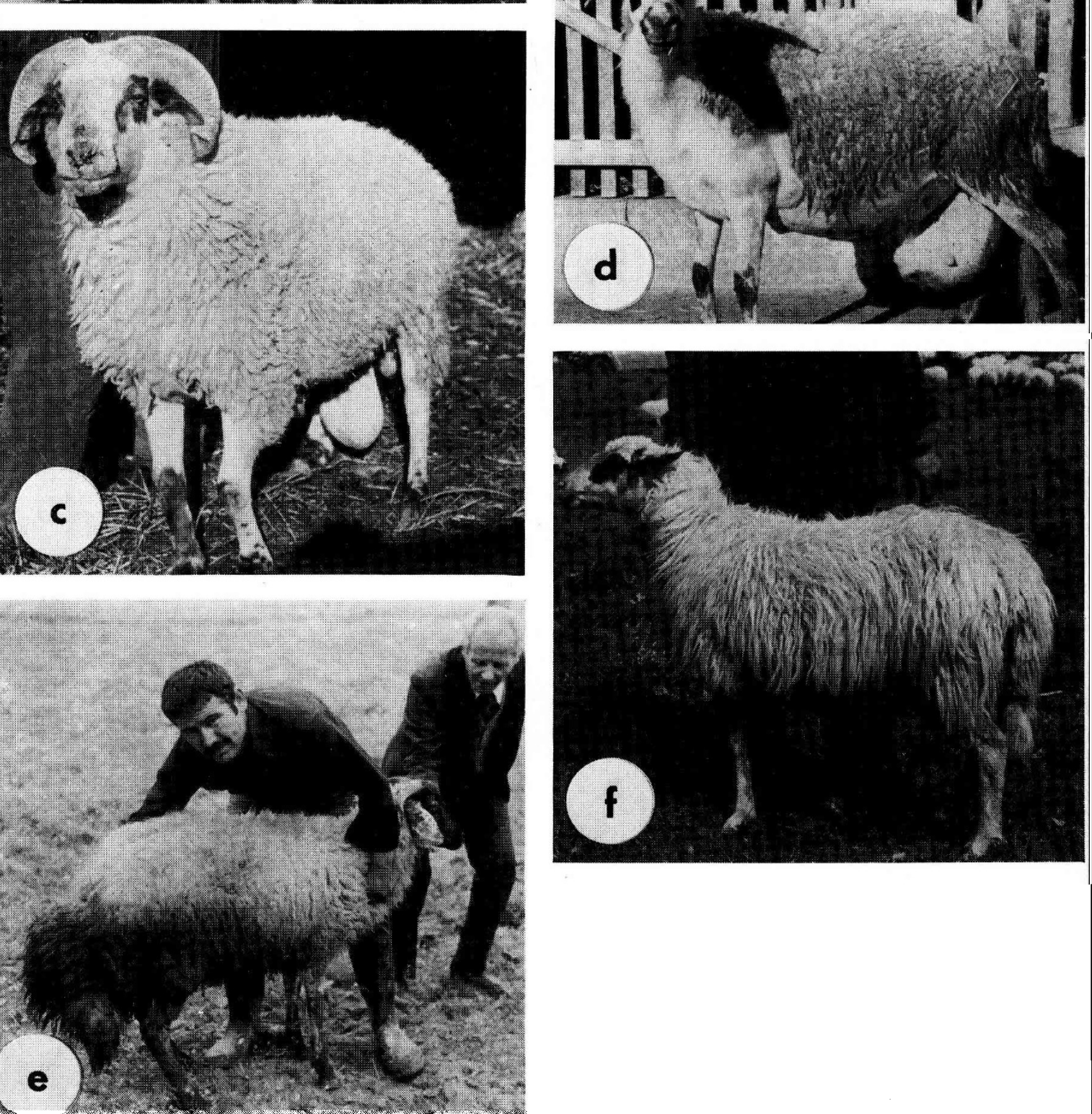

$\sqrt{1} \sqrt{2}$ 1

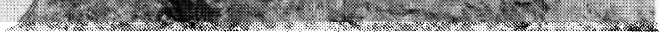


MASON (1967) described the Katafigion as the only migratory breed among the uniform wooled sheep. He gave the fleece weight as I to I.5 kg, and the sheep illustrated (Plate II8) has a "tippy" fleece like a hairy Shetland. The mean fibre diameter of $36 \mu \mathrm{m}$ he quotes is coarser than the wool quality of 50 s to $58 \mathrm{~s}$ he also quotes. Nor does the staple length of $I_{5} \mathrm{~cm}$ warrant the description short.

The ten fleece samples obtained in the present study were variable. Half were hairy, i. e. comparable to the Scottish Blackface type of carpet wool. There was further variation among the remaining finer ones, one being crisp like the British Down type, and one being wavy (2.5 waves per $\mathrm{cm})$.

The staple length ranged from 50 to $180 \mathrm{~mm}$ with a mean of roo. The overall diameter range was from I2 to $\mathrm{II} 4 \mu \mathrm{m}$. The mean mode was $32.6 \mu \mathrm{m}$ (range 30 to $38 \mu \mathrm{m}$ ). The average of the mean diameters was $39.9 \mu \mathrm{m}$ (range $3 \mathrm{r} .6$ to $48.3 \mu \mathrm{m}$ ). The diameter distributions were either symmetrical (four medium fleece types) or skew fine/continuous (three hairy medium and three true hairy fleeces).

One animal was black and had Ioo per cent pigmented fibres, and another had I2 per cent pigmented fibres. Seven animals had medullated fibres, the proportion ranged from $I$ to $I 7$ per cent with a mean of 5.7 per cent.

The sheep with the hairiest coat, and the greatest mean diameter, was the only ore with any medullation in the skin, which amounted to 20 per cent. This animal also had the highest proportion $(33 \%)$ of inactive primaries. The overall mean of inactive primaries was I 5 per cent, and of the secondary follicles 6 per cent. The $\mathrm{S} / \mathrm{P}$ follicle ratio ranged from 2.0 to 4 . I with a mean of $2.9 / \mathrm{I}$.

3. The finer fleeced Chalkidiki is native to the peninsula of the same name southern Macedonia. The numbers are declining, and it was possible to locate only individuals in flocks that are being crossed. The most primitive animal was an all-black yearling ram had horns and a convex nose, and a withers height of $64 \mathrm{~cm}$; ro per cent of the sheep were black (cf. the Drama native breed, above) 1 The general appearance, and the fleece, were like the Shetland breed, but the tai. was longer (medium length). The ewes were polled. The face, legs, and sometines the belly, were black, altough others were white, speckled, or had black around the eyes (fig. $4, b$ ). Some of the white animals had black hairs, which, as in the Shetland breed (RYDER, I968), give rise to grey fleeces, and some dark grey animals were seen.

Four mature ewes ranged in height from 65 to $69 \mathrm{~cm}$, with a mean of $67.25 \mathrm{~cm}$. The sheep were said to be hardy. They do not mate until their second year, the litter size is I.2, but the ewes are fertile until the age of seven or eight years (cf. Drama native breed, above).

Among the brief details of the Chalkidiki breed given by MASON are a ewe fleece weight of $1.4 \mathrm{~kg}$, a staple length of $I_{5} \mathrm{~cm}$, and mean fibre diameter of $36 \mu \mathrm{m}$.

Two fleece samples indicated hairy animals with a mean of $46.4 \mu \mathrm{m}$, a mode of $34 \mu \mathrm{m}$, and $\mathrm{I}_{5}$ per cent medullated fibres. The mean diameter of the remaining four was $33 \mu \mathrm{m}$ and the average mode $25 \mu \mathrm{m}$. Three of these samples had a few hairs (mean proportion of medullated fibres, I2 \%) and were therefore hairy medium wools (cf. hairy Shetland); the remaining animal was a generalized medium wool (cf. woolly Shetland).

The skin samples had a mean of only 5 per cent non-latticed medullation. The smaller amount than in the fleece accords with the time of sampling in winter. There were $3 \mathrm{I}$ per cent of the primaries, and II per cent of the secondary follicles 
inactive, which indicates a tendency to moult the fleece as in the Shetland. The $\mathrm{S} / \mathrm{P}$ ratio of 3.3 was low (cf. Drama native breed).

The general appearance, and fleece measurements, indicate similarities between the Chalkidiki and Drama native breeds. Both appear to be broadly of generalized medium fleece type, the ancient fine wool that from textile remains can be traced back to about 500 BC in the Near East, and which spread through Europe during Roman times (RYDER, I969). It persists in northern Europe in such breeds as the Shetland.

4. The Skopelos (or Glossa), a dairy breed of the Greek Zackel type, was developed on the island of Skopelos in the Northern Sporadhes. The ancestry of the breed is obscure. According to MAson ( 1967 ) there is no record of sheep on Skopelos before I80o, and he considers that a fertile breed with a coarse fleece could have been introduced from St. Eustratios island, and the fleece selected to give the modern Skopelos. His alternative, possible origin from the Chalkidiki breed, seems more likely and is supported by N. P. ZERVAS at the Aristotelian University of Thessaloniki (personal communication).

At the time of our survey (February, I975) the number of mature Skopelos sheep on the island was 97 ( 85 ewes and I 2 rams); the total in I960 was 470 (GEORGIOU, I960). About goo Skopelos sheep are on the mainland, most of them in or near several small towns on the coast south of the city of Volos. Small flocks of the breed are maintained also at Thessaloniki University Farm and at Yannitsa Farm Breeding Station.

During the past fifteen years, land-use on Skopelos has changed to give greater emphasis to horticulture, and increasingly, young persons leave the island to find employment in the cities. Sheep husbandry, which was similar to that described for the Dubrovnik breed has disappeared. Formerly, from one to three ewes were taken out to graze each day and returned to stalls at the house in the evening. Currently, there are only six owners of Skopelos sheep on the island, and their holdings range from eight to twenty animals. Goats have replaced sheep as the source of milk for home consumption. On the mainland, Skopelos sheep are kept in flocks of from 20 to 25 head, which are stall-fed throughout the year. Milk from the ewes is sold to buyers from local cheese factories.

Attempts during the I950's to establish the breed on the mainland failed, with high mortality of sheep. The present flocks of Skopelos in the area south of Volos are descended from breeding stock brought from the island during I964-65 to replace Chios ewes that had become diseased with "parmara ", an udder infection that seriously reduced lactation. With careful husbandry, and especially the provision of supplemental feed, the Skopelos breed now appears to be successfully established on the mainland.

In the course of our survey, the description of the breed by MASON was con firmed, the chief characteristics being precocity and prolificacy (fig. 4, c). Sexual maturity is achieved seven months after birth, with ewes lambing at age I3 to I5 months. Our findings support the statement by GEORGIOU (I96I) that with good management " two lambings a year are easily obtained with parallel multiparity ". His data (for 94 ewes lambing) shows a lambing percentage of 184 , with singles accounting for 37 per cent, twins 45 per cent, triplets I5 per cent, and quadruplets 3 per cent. During our survey, the owner of one flock of Skopelos (at Nea Ankhialos) reported 70 lambs per lambing from the 30 ewes he managed.

The fleece was noticeably finer than that of other Greek breeds, and the wool 
more crimped. The mean fibre diameter of $26 \mu \mathrm{m}$ quoted by MASON accords with the quality number of $50 \mathrm{~s}$ to $56 \mathrm{~s}$ he quotes.

Three groups of five fleece samples were obtained : from the island, and Nea Ankhialos and Yannitsa on the mainland, and skin samples, too, were taken from the latter.

The fleece was in general comparable with that of a British "Down " type, but with a tendency towards a coarser staple tip, which was also greasy, and waviness. The best defined of these had two waves per $\mathrm{cm}$. The sheep on the island had the shortest and finest fleeces, the staple length ranging from 60 to $70 \mathrm{~mm}$ with a mean of $63 \mathrm{~mm}$. The staple length of the Nea Ankhialos samples ranged from $70 \mathrm{~mm}$ to $\mathrm{I} 40 \mathrm{~mm}$ in one uncharacteristically hairy individual with a mean of I $05 \mathrm{~mm}$. That of the Yannitsa animals ranged from 80 to I Io mm with a mean of $93 \mathrm{~mm}$.

Except for the hairy animals, and one with a few hairy fibres, the overall diameter range was from $\mathrm{I} 6 \mu \mathrm{m}$ to $60 \mu \mathrm{m}$ and most animals had a symmetrical diameter distribution, although two had an unusual skewed-to-medium distribution, but nearly all were true medium fleece types on the classification of Ryder (I969). The skewness was so great in one of the Yannitsa samples as to make the mode $50 \mu \mathrm{m}$ which increased the mean mode to $39.8 \mu \mathrm{m}$ compared with 33.3 and $33.4 \mu \mathrm{m}$ in the other two groups (ranges 30 to $40 \mu \mathrm{m}$ and 30 to $37 \mu \mathrm{m}$ ).

The overall mean fibre diameter of the Island group was $34.8 \mu \mathrm{m}$ (range 32.6 to $37.5 \mu \mathrm{m}$ ) while that of the Nea Ankhialos group was $40.7 \mu \mathrm{m}$, which was raised by the mean of $58.7 \mu \mathrm{m}$ in the hairy animal already discussed. If this animal is excluded the mean is reduced to $36.2 \mu \mathrm{m}$ (range 33.6 to $39.5 \mu \mathrm{m}$ ). The mean fibre diameter of the Yannitsa group was $37.8 \mu \mathrm{m}$ (range 35.2 to $42 . \mathrm{I} \mu \mathrm{m}$ ).

Only one of the Yannitsa sheep had any medullated fibres, the proportion being 2 per cent and the overall mean was 0.4 per cent. Four of the Nea Ankhialos animals (including the two hairy animals) had medullated fibres ranging up to 20 per cent of the total, the overall mean being 9.8 per cent. Despite the relatively fineness of the island group, three of the animals had medullated fibres, the proportion ranging up to 28 per cent, making the overall mean 7.6 per cent.

Follicle counts in the skin samples indicated a secondary/primary follicle ratio of 3.7 (range 3.2 to 4.4 ). There were no medullated fibres within the skin which is in keeping with the loss of medullation in winter. A mean of 4 per cent of the primaries and 0.5 per cent of the secondaries were inactive.

5. The Chios breed from the Greek island of the same name is kept in Turkey as the Sakiz, and examples were seen in both countries (fig. 4, d). This semifat tailed type is another fertile breed, and MASON quotes a litter size of I.8.

MASON (I967) considered that the suggested origin from a cross between the Greek Zackel and the Turkish fat-tailed Karaman could not account for the medium quality fleece, and he favoured derivation from a cross between the Turkish Kivircik (finer wool) and Dagliç (fat-tailed) breeds. This is the same origin as the Turkish Kamakuyruk breed of the same area.

According to MAson the fleece is of medium quality (50s-56s) with a staple length of $80 \mathrm{~mm}$. This length accords with figures reported by RYDER (I974) along with a mean diameter of about $27 \mu \mathrm{m}$. The diameter distributions were either true medium, or hairy medium, although there were no more than four per cent medullated fibres.

The wool of the five Chios sheep sampled at Thessaloniki University was coarser than that of the Skopelos breed, being more comparable with that of the 
Scottish Cheviot than the Down type, althoughone had a wave like that in the Border Leicester breed, and another was more hairy, although lacking in kemp.

The staple length ranged from Ioo to $180 \mathrm{~mm}$ with a mean of $132 \mathrm{~mm}$. The mean diameter was $42.7 \mu \mathrm{m}$ (range 36.6 to $46.7 \mu \mathrm{m}$ ). The mean mode was $39.6 \mu \mathrm{m}$ (range 34 to $44 \mu \mathrm{m}$ ). The overall diameter range was from 20 to rio $\mu \mathrm{m}$, which was found in one hairy individual. The diameter distribution was either symmetrical in the three sheep with medium -fleece types, or skew-fine/continuous in the hairy sheep and the one with a hairy medium fleece. Three individuals had medullated fibres, the proportion ranging up to I9 per cent in the hairy animal, with an overall mean of 5.2 per cent.

The skin samples indicated a secondary-primary follicle ratio of 3.5 , with 3 per cent of the primary follicles and 2 per cent of the secondaries inactive (in December).

\section{F. Turkey}

I. In Turkey the Sakiz breed is localized to a narrow zone towards the end of the Erythraen peninsula opposite Chios, and its numbers have declined from about 5000 in recent years to 900 . In one small flock visited, the litter size at lambing was 2.8 and at weaning, 2.3. The main product is milk, the daily yield being quoted as $3 \mathrm{~kg}$.

The Sakiz samples were much coarser than the Chios wool; four of the six samples were very kempy, one had hair instead of kemp, and only one had a denser more woolly fleece. The staple lengths ranged from 55 to $105 \mathrm{~mm}$ with a mean of $79 \mathrm{~mm}$.

The overall fibre diameter range was from $I_{4}$ to $I 80 \mu \mathrm{m}$, the modes ranged from 22 to $26 \mu \mathrm{m}$ with a mean mode of $24.3 \mu \mathrm{m}$. The mean diameters ranged from $3 \mathrm{I} .8 \mu \mathrm{m}$ to $48.5 \mu \mathrm{m}$ giving an overall mean for the breed of $40.9 \mu \mathrm{m}$. Each animal had a skew-fine/continuous fibre diameter distribution, and the fleece was of true hairy type. Every animal had medullated fibres the incidence ranging from 5 per cent to 23 per cent, giving a mean of 16.3 per cent. One animal had ro per cent of pigmented fibres, giving an overall mean of 1.7 per cent pigmented fibres for the group of sheep.

2. The local Odemis breed, not listed by MAson (I967) but described by Sönmez (1966), was seen at Ege University farm and near Ödemis in the Küçük Menderes valley.

It is a mostly polled, fat-tailed breed with lop ears; one flock had brown, and the other, black faces (fig. 4,e). The tail is short, broad and twisted. There are no clear indications of the origin of this breed, although a cross between the Dağliç and a fine wooled breed is a possibility.

The fleece appeared variable, some animals had a double coat reminiscent of that of " hair " sheep with a coarse, brittle, outer coat, and fine underwool. Others apparently had a generalized medium type of fleece comparable with the Chalkidiki of Greece.

The five animals sampled at Ege had staple lengths ranging from 30 to $50 \mathrm{~mm}$ with a mean of $37 \mathrm{~mm}$. The two at Odemis had obviously not yet been shorn and had fleeces 95 and $\mathrm{I} 45 \mathrm{~mm}$ in length. The overall diameter range was from I2 $\mu \mathrm{m}$ to $\mathrm{I} 36 \mu \mathrm{m}$, the modes from 20 to $30 \mu \mathrm{m}$ with a mean of $22.8 \mu \mathrm{m}$ and the means from $32.6 \mu \mathrm{m}$ to $42.2 \mu \mathrm{m}$ with an overall mean of $36.8 \mu \mathrm{m}$. 
One animal had a skew-fine diameter distribution and was of hairy medium type; the remainder had a continuous distribution, and so were true hairy fleeces. Every animal had medullated fibres, the incidence ranging from 2 per cent to 26 per cent with a mean of $I 7$ per cent. Three animals had pigmented fibres, the maximum proportion being 20 per cent and the overall mean 4 per cent.

Skin samples were obtained from the five animals at Ege, and in these a mean of 62 per cent of the primaries, and 23 per cent of the secondaries were inactive. Two animals had some primary fibres with a non-latticed medulla, the overall mean being 3.4 per cent. The $\mathrm{S} / \mathrm{P}$ follicle ratio ranged from 3.6 to 5.2 , giving a mean of $4.5 / \mathrm{I}$. This is a relatively high figure for a hairy breed, and is the same as that of the Sakiz.

3. The Imroz breed takes its name from the Turkish island $15 \mathrm{~km}$ west of the Gallipoli Peninsula. The breed is also found on the mainland of Turkey in the area between the towns of Canakkale and Ezine. The total number of Imroz is about 30,00o (Sandikcioğlu, personal communication). Production is for milk (by estimated value 60 per cent), lamb (35 per cent), and wool ( 5 per cent). Imroz are reported to be hardy, resistant to cold weather, and relatively free of disease.

The breed was seen at Kumkale Animal Breeding Station, where the Turkish Government maintains 979 pure-bred Imroz. The fleece is white and covers the top of the head and the trunk to the belly, which is bare (fig. 4, f). Commonly black - or reddish-brown - patches occur around the eyes, the nose, and the tips of the ears. The head is narrow; the bridge of the nose straight in profile. Legs are white and bare of wool. The tail is of medium width, reaching to just below the hocks. About two-thirds of the ewes seen at Kumkale were polled; the remainder had small scurs. Rams develop horns which spread widely in open spiral (very much like those of Sopravissana rams seen in central Italy). Wither heights were recorded at the station for six ewes and one ram. The values for the ewes ranged from $60 \mathrm{~cm}$ to $67 \mathrm{~cm}$, with $62.8 \mathrm{~cm}$ the mean; the ram was $7 \mathrm{r} \mathrm{cm}$. Live weight is reported to be from 35 to $40 \mathrm{~kg}$ (ÖZCAN, I972, p. I9).

Lambing occurs once a year, and at the rate of I29 per cent at Kumkale Station; elsewhere (according to ÖZCAN) from II2 per cent to I20 per cent. Annual milk production per ewe varies widely-from $50 \mathrm{~kg}$ to $\mathrm{I}_{50} \mathrm{~kg}$.

The breed is shorn twice a year; annual wool production per head is about $\mathrm{I} .5 \mathrm{~kg}$ to $2 \mathrm{~kg}$. The fleece, which hangs in curled locks $25 \mathrm{~cm}$. to $30 \mathrm{~cm}$. long, is not uniform in quality. "Although the average fibre diameter is $35-40 \mu \mathrm{m}$, coarse wiry examples $36 \mathrm{~s}$ to $40 \mathrm{~s}$ in quality are found, and the value of the wool is correspondingly low "(ÖzCAN, I972, p. I8).

Twelve Imroz fleece samples ranged in length from 60 to $160 \mathrm{~mm}$ with a mean of $123.3 \mathrm{~mm}$. Most samples appeared hairy, with a hairy tip, and varying proportions of kemp and underwool, being typical of carpet wool type; four were black.

The overall fibre diameter range was from I 2 to $\mathrm{I} 94 \mu \mathrm{m}$, and the modes ranged from 20 to $34 \mu \mathrm{m}$. with a mean of 25 . I $\mu \mathrm{m}$. The mean diameters ranged from $3 \mathrm{I} .0$ to $46.8 \mu \mathrm{m}$ with an average of $36.5 \mu \mathrm{m}$. Most of the diameter distributions were skew-fine to continuous, and so typical of a hairy type, but two with hairs no greater than $70 \mu \mathrm{m}$ in diameter had skewfine distributions, and so were hairy medium wools.

Every sample had some medullated fibres which ranged in incidence from 3 to 24 per cent with a mean of I2 per cent. Only two of the six skin samples had any medullated fibres, possibly because of the season of sampling, the overall 
mean being 2 per cent. An overall mean of 3I per cent of the primary follicles, and 8 per cent of the secondaries were inactive. The $S / P$ follicle ratio ranged from $4 . \mathrm{I}$ to 5.8 with a mean of $4.5 / \mathrm{I}$, which is a relatively high value for a hairyfleeced type.

\section{Conclusions}

Breeds are usually thought to decline because they have become uneconomic, and this is true of such breeds as the Chalkidiki and even the Spanish Merino. The present survey has shown that other factors, including demographic change and the impact of new socio-economic mobility in rural communities, contribute markedly to the decline and extinction of breeds. And, if a husbandy system is becoming disused, the breed associated with it, e.g., Dubrovnik, Skopelos, will decline. But clearly, decisions as to whether or not a breed should be preserved must be based on the need to maintain genetic diversity, and not on the vagaries of the economic value of the breed.

The question of declining breeds with the consequent loss of genetic resources is complicated by the lack of basic information, such as breed numbers and location, genetic characteristics, management, and the nature of the natural and cultural milieu in which the breed is found. For this reason, the problem is best approached through interdisciplinary cooperative effort, including field investigation by a team of research workers from the biological, physical, and social sciences. Within the biological sphere, specialist attention to such aspects as genes with visible effects, blood type, and milk protein is necessary, in addition to fleece type which has been emphasized in the present paper.

Reçu pour publication en mai 1977.

\section{Acknowledgments}

We wish to thank the many people in the different countries visited for their help in providing information and access to flocks.

\section{Résumé}

Caractéristiques de quelques races ovines à effectits restreints eu Europe du Sud Un aperçu préliminaire

Au cours d'une étude sur le terrain consacrée aux moutons méditerranéens et menée de septembre 1974 à août 1975 cinquante trois races ont été passées en revue. Douze d'entre elles sont étudiées dans le présent article : Mérinos espagnol, Rouge du Levant (Espagne); Peone (France); Carapelle (Italie); Doubrovnik (Yougoslavie); Drama indigène, Katafigion, Chalchidique, Skopelos (Grèce); Sakiz, Imroz, Ödemis (Turquie). Les facteurs responsables du déclin des races en voie de disparition ont été identifiés. La localisation de chaque race est exposée brièvement ainsi que l'effectif actuel et ses tendances, les caractéristiques morphologiques, les performances, la conduite de l'élevage et les qualités d'adaptation au milieu. L'examen d'échantillon de toison et de peau, révèle que certaines de ces races ont quelques affinités avec le type à laine fine. 


\section{References}

Baticle Y., 1974. L'Élevage Ovin dans les Pays Europeens de la Mediterranee Occidental, p. I70, 47I, Société les Belles Lettres, Paris, pp 598.

Catsaounis N., i975. ПроватотрофіA. Thessaloniki, pp 360.

F.A.O., 1975. Pilot Study on Conservation of Animal Genetic Resources, Rome, pp 6o.

Georgrou A., 196o. Sheep and goat raising in Greece. Paper to Meeting of Experts Organised by F.A.O. and E.A.A.P. on Production and Utilisation of Sheep and Goat Milk in the Mediterranean Area, Athens. MiS.

Gilbert L., r975a. Races ovines françaises en peril. In: Races Domestiques en Peril; Ethnozootechnie, Numéro Special, 6r-66.

Gilbert L., 1975 $b$. Personal communication.

Karantunias A. G., I974. Personal communication.

Lauvergne J. J., I975. Disappearing cattle breeds in Europe and the Mediterranean Basin. In Pilot Study on Conservation of Animal Genetic Resources. FAO and PNUE, Rome, Annex 2, $2 \mathrm{I}-42$.

LYDEKKER R., I9I2. The Sheep and Its Cousins, pp 76, George Allen, London.

MAson I. L., 1967. The Sheep Breeds of the Mediterranean, F.A.O., and Commonwealth Agricultural Bureau, Farnham Royal, England, pp 215.

Mason I. L., I969. A World Dictionary of Livestock Breeds, Types, and Varieties. Commonwealth Agricultural Bureaux, Farnham Royal, England, pp 268.

Nikolic D., I962. Rase $i$ Sojevi Ovaca u FNR Jugoslaviji. I962. pp 25.

Özcan H., I972. Koyun Keci Yetistivicilǐ̆i Yagaği ve Tiftik Bilgisi, Yonca Matbaasi. pp Ir6.

Pediglieri V., I973. Le Lane d'Italia. Associazione Nazionale della Pastorizia. (Rome). I5I p.

Ryder M. L., r963. Some measurements of old Merino wool. Austral. J. Sci., 25, 499-502.

RYDER M. L., 1968. Fleece structure in some native and unimproved breeds of sheep. $Z$. $f$. Tievzuchtung und Zuchtungsbiologie 85, 143-1 70.

Ryder M. L., I969. Changes in the fleece of sheep following domestication (with a note on the coat of cattle). In : Ucko, P. J. and Dimbleby, G. W. (eds). The Domestication and Exploitation of Plants and Animals, 495-52 r, Duckworth, London.

RYDER M. L., I974. Fleece measurements of some miscellaneous native and unimproved breeds. J. Text. Inst., 65, 13-19.

Sanchez Belda A., i 974 . Personal communication.

SANChez BELdA A., 1976. Los ovinos de raza Roja Levantina. Avances en Alimentacion y Mejora Animal,4, 3-1x.

Sandicioglu M., I975. Personal communication.

Sönmez R., 1966. Koyunculuk ve Yapagi. Izmir, Ege University.

Terrill C. E., Sheep Breeds of the World, 1970. Paper presented at 62nd Annual Mieeting American Society of Animal Science, Pennsylvania State University, August 3, 1970. pp r6o.

Zervas N. P., 1975. Personal communication.

Zervas N., Boyazoglu P., Kalaissakis P., Papadimitriout T., Flamant J. C. Comparison des races ovines Chios et Frisonne avec leurs croisements, en Grèce Continentale. Ann. Genet. Sel. Anim., 1975. 7, 277-291. 